\title{
Prokineticin Receptor 1 Antagonist PC-10 as a Biomarker for Imaging Inflammatory Pain
}

\author{
Orit Jacobson ${ }^{1}$, Ido D. Weiss ${ }^{2}$, Gang Niu ${ }^{1}$, Gianfranco Balboni ${ }^{3}$, Cenzo Congiu ${ }^{3}$, Valentina Onnis ${ }^{3}$, Dale O. Kiesewetter ${ }^{1}$, \\ Roberta Lattanzi ${ }^{4}$, Severo Salvadori ${ }^{5}$, and Xiaoyuan Chen ${ }^{1}$ \\ ${ }^{1}$ Laboratory of Molecular Imaging and Nanomedicine, National Institute of Biomedical Imaging and Bioengineering, National \\ Institutes of Health, Bethesda, Maryland; ${ }^{2}$ Laboratory of Molecular Immunology, National Institute of Allergy and Infectious \\ Diseases, National Institutes of Health, Bethesda, Maryland; ${ }^{3}$ Department of Toxicology, University of Cagliari, Cagliari, Italy; \\ ${ }^{4}$ Department of Physiology and Pharmacology Vittorio Erspamer, Sapienza University Rome, Rome, Italy; and ${ }^{5}$ Department of \\ Pharmaceutical Sciences and Biotechnology Center, University of Ferrara, Ferrara, Italy
}

\begin{abstract}
Prokineticin receptor 1 (PKR1) and its ligand Bv8 were shown to be expressed in inflammation-induced pain and by tumorsupporting fibroblasts. Blocking this receptor might prove useful for reducing pain and for cancer therapy. However, there is no method to quantify the levels of these receptors in vivo. Methods: A nonpeptidic PKR1 antagonist, $N$-\{2-[5-(4-fluorobenzyl)-1-(4-methoxy-benzyl)-4,6-dioxo-1,4,5,6-tetrahydro-[1,3,5] triazin-2-ylamino]-ethyl\}-guanidine, which contains a free guanidine group, was labeled with ${ }^{18} \mathrm{~F}$ by reacting the guanidine function with $N$-succinimidyl-4-18 F-fluorobenzoate to give the guanidinyl amide $N$-(4-18F-fluoro-benzoyl)- $N^{\prime}-\{2-[5-(4-$ fluorobenzyl)-1-(4-methoxy-benzyl)-4,6-dioxo-1,4,5,6-tetrahydro-[1,3,5] triazin-2-ylamino]-ethyl\}-guanidine ( $\left.{ }^{18} \mathrm{~F}-\mathrm{PC}-10\right)$. Inflammation was induced in C57BL/6 mice by subcutaneous injection of complete Freund adjuvant in the paw. The mice were imaged with ${ }^{18} \mathrm{~F}-\mathrm{PC}-$ 10, ${ }^{18} \mathrm{~F}-\mathrm{FDG}$, and ${ }^{64} \mathrm{Cu}$-pyruvaldehyde bis(4-methyl-3-thiosemicarbazone) ( $\left.{ }^{64} \mathrm{Cu}-\mathrm{PTSM}\right)$ at $24 \mathrm{~h}$ after complete Freund adjuvant injection using a small-animal PET device. Results: ${ }^{18} \mathrm{~F}-\mathrm{PC}-10$ was synthesized with a radiochemical yield of $16 \% \pm 3 \%$ (decay-corrected). ${ }^{18} \mathrm{~F}-\mathrm{PC}-10$ accumulated specifically in the inflamed paw 4- to 5-fold more than in the control paw. Compared with ${ }^{18} \mathrm{~F}-\mathrm{PC}-10,{ }^{18} \mathrm{~F}-\mathrm{FDG}$ and ${ }^{64} \mathrm{Cu}-\mathrm{PTSM}$ displayed higher accumulation in the inflamed paw but also had higher accumulation in the control paw, demonstrating a reduced signal-to-background ratio. ${ }^{18} \mathrm{~F}-\mathrm{PC}-10$ also accumulated in PKR1-expressing organs, such as the salivary gland and gastrointestinal tract. Conclusion: ${ }^{18} \mathrm{~F}-\mathrm{PC}-10$ can be used to image PKR1, a biomarker of the inflammation process. However, the high uptake of ${ }^{18} \mathrm{~F}-\mathrm{PC}-10$ in the gastrointestinal tract, due to specific uptake and the metabolic processing of this highly lipophilic molecule, would restrict its utility.
\end{abstract}

Key Words: prokineticin receptor; inflammation; positron emission tomography (PET); ${ }^{18} \mathrm{~F}$

J Nucl Med 2011; 52:600-607

DOI: 10.2967/jnumed.110.084772

Received Oct. 29, 2010; revision accepted Dec. 28, 2010.

For correspondence or reprints contact: Xiaoyuan Chen, Laboratory of Molecular Imaging and Nanomedicine, National Institute of Biomedical Imaging and Bioengineering, National Institutes of Health, Bethesda, MD 20892.

E-mail: shawn.chen@nih.gov

COPYRIGHT $\odot 2011$ by the Society of Nuclear Medicine, Inc.
$\mathbf{P}$ rokineticin receptor 1 (PKR1) and prokineticin receptor 2 (PKR2) are closely related G-protein-coupled receptors (1-3). PKR1 is widely distributed in the peripheral tissues, including the gastrointestinal system, lungs, blood leukocytes, spleen, pancreas, testes, salivary gland, and endocrine glands $(1,4)$. The messenger RNA of both PKR1 and PKR2 is expressed in the gastrointestinal system. However, whereas PKR1 is abundantly expressed in the stomach, small intestine, colon, rectum, and other gastrointestinal tissues, PKR2 is expressed only in the ileocecum, suggesting that PKR1 has a major role in the mediation and regulation of gastrointestinal motility (1). PKR2 is also highly expressed in discrete nuclei of the central nervous system $(1,5,6)$.

The prokineticin Bv8 - one of the ligands of PKR1-is a small protein $(8 \mathrm{kDa})$ rich in cysteine residues, which was isolated from the skin secretion of the frog Bombina variegata $(5,7,8)$. Homologs of Bv8 were found in skin secretions of other amphibians, lizards, and fish (5). Mamba intestinal toxin-1 (MIT-1), found in the venom of the black mamba, is another Bv8 homolog (5). The mammalian homologous proteins of Bv8 are prokineticin 1 (or vascular endothelial growth factor) and prokineticin 2 (or mBV8) $(5,8,9)$.

Prokineticin proteins have been shown to promote angiogenesis, mainly in several endocrine organs (10-12). These proteins are also involved in other biologic processes such as reproduction, neuronal survival, neurogenesis, control of circadian rhythms, and cancer $(5,8,10,13-15)$. Another reported function of prokineticin proteins is to stimulate the contraction of the isolated guinea pig ileum and relaxation of the colon $(7,9,16)$. Prokineticin 2 , but not prokineticin 1 , is highly expressed in the bone marrow, lymphoid organs, and leukocytes, suggesting a role for prokineticin 2 in hematopoiesis and in inflammatory and immunomodulatory processes $(17,18)$. Prokineticin 2 also plays a role in the regulation of tumor-supporting myeloid cells (19). Shojaei et al. showed that Bv8 plays a role in the mobilization of tumor angiogenesis, promoting myeloid cells from the bone marrow during tumor development (19). 
The prokineticin 2-PKR1 axis plays a major role in pain perception (4). Furthermore, reduction in the pain threshold produced by prokineticin 2 acting on prokineticin receptors in sensory neurons indicates that Bv8 and prokineticin and their receptors may act as mediators of inflammatory and neuropathic pain (20-22). Giannini et al. showed that the prokineticin 2-PKR1 axis plays a role in inflammationrelated pain, demonstrating that prokineticin 2 released by inflammatory cells can bind to activated PKR 1 on primary sensitive neurons and contribute to inflammatory pain (23). Blocking the prokineticin 2-PKR1 axis might prove useful for reducing pain and for cancer therapy.

To this end, several nonpeptidic prokineticin antagonists have been developed (24-28). However, there is no method to quantify the levels of PKR1 in vivo, to guide appropriate treatment of candidates. In this study, we developed a biomarker based on the nonpeptidic PKR1 antagonist $N$ - $\{2$-[5-(4-fluorobenzyl)-1-(4-methoxy-benzyl)-4,6-dioxo-1,4,5,6-tetrahydro[1,3,5]triazin-2-ylamino]-ethyl\}-guanidine (PC-7) (Fig. 1) for the noninvasive quantification of PKR1 in an inflammatory pain model using PET. PC-7 contains a free guanidine group and was labeled with the PET isotope ${ }^{18} \mathrm{~F}$ by coupling the guanidine function to $\mathrm{N}$-succinimidyl fluorobenzoate $\left({ }^{18} \mathrm{~F}-\mathrm{SFB}\right)$, to give $N$-(4- ${ }^{18} \mathrm{~F}-$ fluoro-benzoyl)- $N^{\prime}-\{2$-[5-(4-fluoro-benzyl)-1-(4-methoxy-benzyl)-4,6-dioxo-1,4,5,6-tetrahydro-[1,3,5]triazin-2-ylamino]-ethyl $\}$-guanidine ( $\left.{ }^{18} \mathrm{~F}-\mathrm{PC}-10\right)$ (Fig. 1). ${ }^{18} \mathrm{~F}-\mathrm{PC}-10$ was further evaluated as a biomarker in mice injected with complete Freund adjuvant (CFA), which was shown to induce inflammatory pain by upregulation of prokineticin 2 and PKR1 (23).

\section{MATERIALS AND METHODS}

\section{Chemistry}

General Methods. Compounds were purified by preparative reversed-phase high-performance liquid chromatography (HPLC) ( $\delta$-Prep 4000 system with a Prep LC 40-mm assembly column C18; $30 \times 4 \mathrm{~cm}, 15-\mu \mathrm{m}$ particles; Waters) and eluted at a flow rate of 20
$\mathrm{mL} / \mathrm{min}$ with mobile phase solvent $\mathrm{A}(10 \%$ acetonitrile $+0.1 \%$ trifluoroacetic acid [TFA] in $\mathrm{H}_{2} \mathrm{O}$, v/v) and a linear gradient from $10 \%$ to $60 \% \mathrm{~B}\left(60 \%\right.$, acetonitrile $+0.1 \%$ TFA in $\mathrm{H}_{2} \mathrm{O}$, v/v) for 25 min. Analytic HPLC analyses were performed with a System Gold device (Ultrasphere ODS Column, $250 \times 4.6 \mathrm{~mm}$, 5- $\mu \mathrm{m}$ particles; Beckman). Analytic determinations and the capacity factor $\left(K^{\prime}\right)$ of the products used for HPLC in solvents A and B were programmed at flow rate of $1 \mathrm{~mL} / \mathrm{min}$ with linear gradients from $0 \%$ to $100 \% \mathrm{~B}$ for $25 \mathrm{~min}$. The analogs had less than $5 \%$ impurities at 220 and $254 \mathrm{~nm}$.

The molecular weights of the compounds were determined by a matrix-assisted laser desorption ionization time of flight analysis (G2025A LD-TOF system mass spectrometer; Hewlett Packard) and $\alpha$-cyano-4-hydroxycinnamic acid as a matrix. ${ }^{1} \mathrm{H}-\mathrm{NMR}(\delta)$ spectra were measured, when not specified, in dimethylsulfoxide$d_{6}$ solution using a spectrometer (AC-200; Bruker), and peak positions are given in parts per million downfield from tetramethylsilane as an internal standard. PC-7 was synthesized according to a published procedure (29).

Synthesis of $\mathrm{PC}$ - 10 . PC-7 (1 equivalent) and $\mathrm{LiOH} \bullet \mathrm{H}_{2} \mathrm{O}$ ( 3 equivalents) were dissolved in dimethylformamide. The solution was stirred in an oil bath at $100^{\circ} \mathrm{C}$; 4-fluorobenzoic acid (1 equivalent), $\mathrm{N}$-(3dimethylaminopropyl)- $N$ '-ethylcarbodiimide hydrochloride (1.1 equivalent), and 1-hydroxybenzotriazole (1.1 equivalent) were added in 1 pot as solids. After $1 \mathrm{~h}$ at $100^{\circ} \mathrm{C}$, the solvent was evaporated and the residue purified by preparative HPLC: yield $40 \%$; HPLC $K^{\prime} 5.88 ; \mathrm{m} / z, 564.6$ $(\mathrm{M}+\mathrm{H})^{+} ;{ }^{1} \mathrm{H}-\mathrm{NMR}$ (dimethylsulfoxide- $\left.d_{6}\right) \delta 2.50-2.57(\mathrm{~m}, 4 \mathrm{H}), 3.72$ (s, 3H), 4.86 (s, 2H), 5.06 (s, 2H), 6.65-7.93 (m, 12H).

\section{Radiochemistry}

General Methods. Kryptofix 2.2.2 was purchased from EMD Chemicals. All other solvents and chemicals were purchased from Sigma-Aldrich Co. Pyruvaldehyde bis(4-methyl-3-thiosemicarbazone) (PTSM) was purchased from ABX GmbH. ${ }^{18}$ F-fluoride was obtained from the National Institutes of Health Clinical Center cyclotron facility from the irradiation of an ${ }^{18} \mathrm{O}$-water target by the ${ }^{18} \mathrm{O}(p, n){ }^{18} \mathrm{~F}$ nuclear reaction. $\mathrm{C}_{18}$ cartridges (Waters Corp.) were each activated with $5 \mathrm{~mL}$ of ethanol and $10 \mathrm{~mL}$ of water. ${ }^{18} \mathrm{~F}-\mathrm{FDG}$ was purchased from Cardinal Health. ${ }^{64} \mathrm{Cu}$-PTSM was synthesized according to a published procedure (30).

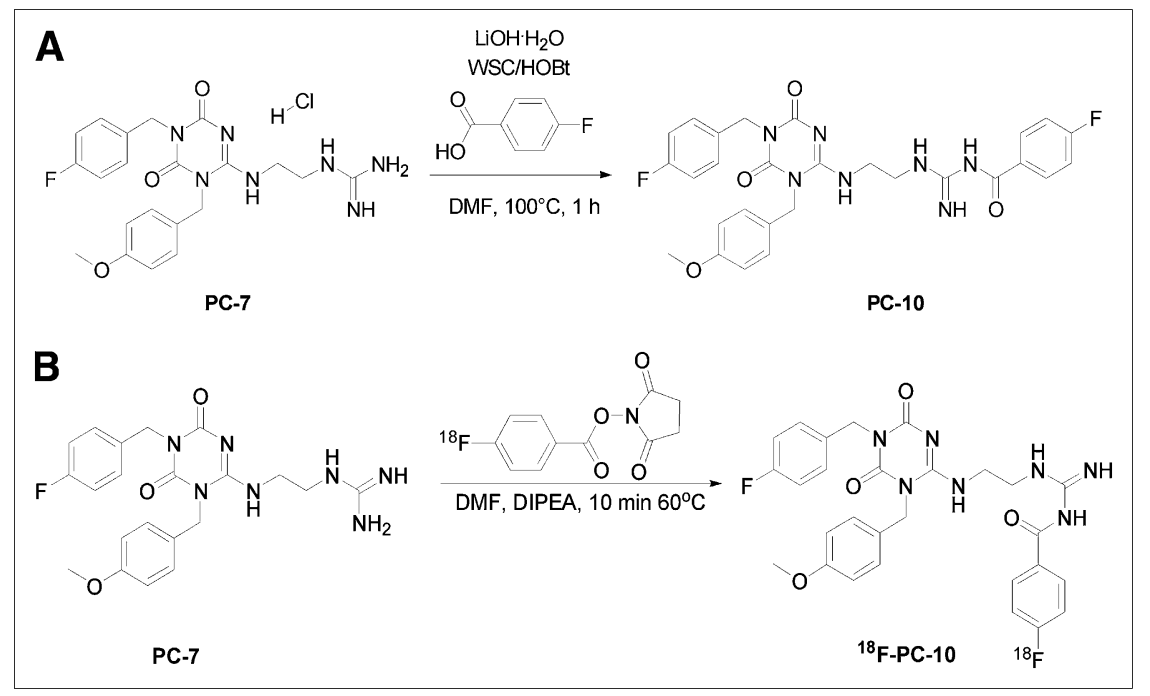

FIGURE 1. (A) Nonradioactive synthesis of $\mathrm{PC}-10$. (B) Radioactive synthesis of ${ }^{18} \mathrm{~F}-\mathrm{PC}$ 10. DIPEA = diisopropylethyl amine; $\mathrm{DMF}=$ dimethylformamide; HOBt = 1-hydroxybenzotriazole; WSC $=N$-(3-dimethylaminopropyl)$N$ '-ethylcarbodiimide hydrochloride. 
Radiosynthesis of ${ }^{18} \mathrm{~F}-\mathrm{PC}-10 .{ }^{18} \mathrm{~F}-\mathrm{PC}-10$ was synthesized in 2 radiochemical steps: radiosynthesis of ${ }^{18} \mathrm{~F}-\mathrm{SFB}$ and coupling of ${ }^{18} \mathrm{~F}-\mathrm{SFB}$ with $\mathrm{PC}-7$ to give the desired product ${ }^{18} \mathrm{~F}-\mathrm{PC}-10 .{ }^{18} \mathrm{~F}-$ SFB was radiosynthesized on a modular system (Eckert \& Ziegler Eurotope $\mathrm{GmbH}$ ) according to a published procedure $(31) .{ }^{18} \mathrm{~F}$ SFB was redissolved in $150 \mu \mathrm{L}$ of dimethylformamide. PC-7 (200 $\mu \mathrm{g}$ in $50 \mu \mathrm{L}$ of dimethylformamide) was added, followed by $20 \mu \mathrm{L}$ of diisopropylethyl amine, and incubated at $60^{\circ} \mathrm{C}$ for $10 \mathrm{~min}$.

${ }^{18} \mathrm{~F}-\mathrm{PC}$-10 was purified on a reversed-phase HPLC system using a Vydac C4 (214TP510, $5 \mu \mathrm{m}, 10 \times 250 \mathrm{~mm}$; Grace) column. The flow was set at $4 \mathrm{~mL} / \mathrm{min}$ using a gradient system starting from $70 \%$ solvent $\mathrm{A}$ and $30 \%$ solvent $\mathrm{B}$ and increasing to $35 \%$ solvent $\mathrm{A}$ and $65 \%$ solvent $\mathrm{B}$ at $30 \mathrm{~min}$. The retention time (Rt) of ${ }^{18} \mathrm{~F}-\mathrm{PC}-10$ on this system was $15.1 \mathrm{~min}$. The HPLC solution of ${ }^{18} \mathrm{~F}-\mathrm{PC}-10$ was diluted with $10 \mathrm{~mL}$ of water and loaded on an activated C-18 cartridge. The cartridge was washed with $10 \mathrm{~mL}$ of water, and ${ }^{18} \mathrm{~F}-\mathrm{PC}-10$ was eluted with $80 \%$ ethanol. The ethanol was completely evaporated under a stream of argon, and ${ }^{18} \mathrm{~F}-\mathrm{PC}-10$ was formulated in saline with the addition of $50 \mu \mathrm{L}$ of dimethylsulfoxide, to prevent tackiness to the glass tube.

${ }^{18} \mathrm{~F}-\mathrm{PC}-10$ quality control was monitored using analytic reversed-phase HPLC on a Vydac C4 (214TP5415, $5 \mu \mathrm{m}, 4.6 \times$ $150 \mathrm{~mm}$ ) column with a gradient system starting from $100 \%$ solvent $\mathrm{A}(0.1 \%$ TFA in water) and $0 \%$ solvent $\mathrm{B}(0.1 \%$ TFA in acetonitrile) for $5 \mathrm{~min}$ and increasing to $50 \%$ solvent $\mathrm{A}$ and $50 \%$ solvent $\mathrm{B}$ at $30 \mathrm{~min}$ (flow, $1 \mathrm{~mL} / \mathrm{min}$; Rt, $25.81 \mathrm{~min}$ ). The ultraviolet absorbance was monitored at $254 \mathrm{~nm}$, and the identification of ${ }^{18} \mathrm{~F}-\mathrm{PC}-10$ was confirmed by a coinjection with unlabeled PC-10. The Rt of unlabeled PC-10 was $25.65 \mathrm{~min}$.

\section{Biology}

Chinese Hamster Ovarian (CHO)-PKR1 and CHO-PKR2 Cell Culture. CHO-PKR1 and CHO-PKR2 cell lines were kindly provided by Dr. Qun-Yong Zhou from the University of California-Irvine. The cells were grown in Dulbecco's modified Eagle's medium (Gibco) supplemented with $10 \%$ (v/v) fetal bovine serum under $5 \% \mathrm{CO}_{2}$ at $37^{\circ} \mathrm{C}$.

Competition Cell-Binding Assay. PKR1 and PKR2 binding was assayed to determine binding affinities of PC-10. Briefly, CHOPKR1 and CHO-PKR2 cells were cultured in Dulbecco's modified Eagle's medium with fetal bovine serum. When cells reached $80 \%$ confluence, they were scraped off and suspended with binding buffer (20 mM Tris- $\mathrm{HCl}, \mathrm{pH} 7.4,150 \mathrm{mM} \mathrm{NaCl}, 2 \mathrm{mM} \mathrm{CaCl}_{2}$, $1 \mathrm{mM} \mathrm{MgCl}$, and $1 \mathrm{mM} \mathrm{MnCl} 2,0.1 \%$ bovine serum albumin) for a final concentration of $2 \times 10^{6}$ cells $/ \mathrm{mL}$. In a 96-well plate, $1 \times 10^{5}$ of either CHO-PKR1 or CHO-PKR2 cells per well were incubated with $1.11 \mathrm{kBq} /$ well $\left(0.03 \mu \mathrm{Ci} /\right.$ well) of ${ }^{125} \mathrm{I}$-MIT-1 (PerkinElmer) in binding buffer in the presence of different concentrations of PC-10 at room temperature for $2 \mathrm{~h}$. After incubation, the plate was washed 3 times with phosphate-buffered saline (PBS), and the radioactivity was measured by $\gamma$-counting. The inhibitory concentration of $50 \%\left(\mathrm{IC}_{50}\right)$ was calculated by nonlinear regression analysis using the GraphPad Prism computer-fitting program (GraphPad Software, Inc.). Each data point is a result of the average of duplicate wells.

Cell Uptake, Internalization, and Efflux Studies. For cell uptake studies, CHO-PKR1 cells were seeded into a 24-well plate at a density of $1 \times 10^{5}$ cells per well and incubated with $444 \mathrm{kBq} /$ well $(12 \mu \mathrm{Ci} /$ well $)$ of ${ }^{18} \mathrm{~F}-\mathrm{PC}-10$ at $37^{\circ} \mathrm{C}$ for $15,30,60$, and $120 \mathrm{~min}$. Tumor cells were then washed twice with cold PBS and harvested by addition of $250 \mu \mathrm{L}$ of $0.1 \mathrm{M} \mathrm{NaOH}$. Internalization studies were performed similarly to the procedure described for the cell uptake studies. After 15, 30, 60, and $120 \mathrm{~min}$ of incubation of CHO-PKR1 cells with ${ }^{18} \mathrm{~F}-\mathrm{PC}-10$ at $37^{\circ} \mathrm{C}$, the cells were washed twice with cold PBS and then incubated for $1 \mathrm{~min}$ with acid-washing buffer (50 $\mathrm{mmol} / \mathrm{L}$ glycine, $0.1 \mathrm{M} \mathrm{NaCl}, \mathrm{pH} 2.8$ ) to remove surface-bound radioactive ligand. Thereafter, the cells were washed twice with cold PBS and harvested by addition of $250 \mu \mathrm{L}$ of $0.1 \mathrm{M} \mathrm{NaOH}$. For efflux studies, $444 \mathrm{kBq} /$ well $(12 \mu \mathrm{Ci} /$ well $)$ of ${ }^{18} \mathrm{~F}-\mathrm{PC}-10$ were added to CHO-PKR1 cells in a 24-well plate and incubated for $2 \mathrm{~h}$ at $37^{\circ} \mathrm{C}$. Then cells were washed twice with cold PBS and incubated with Dulbecco's modified Eagle's medium for 15, 30, 60, and $120 \mathrm{~min}$. After being washed twice with PBS, cells were harvested by addition of $250 \mu \mathrm{L}$ of $0.1 \mathrm{M} \mathrm{NaOH}$. The cell suspensions were collected and measured in a $\gamma$-counter (1480 Wizard 3; PerkinElmer). Each data point is an average of triplicate wells.

CFA Inflammation Model. CFA (Sigma-Aldrich) was emulsified with PBS in a 1:1 ratio and injected subcutaneously into the paw in a volume of $20 \mu \mathrm{L}$. Inflammation-induced pain was shown to peak at $24 \mathrm{~h}$ after CFA injection; hence, ${ }^{18} \mathrm{~F}-\mathrm{PC}-10,{ }^{18} \mathrm{~F}-\mathrm{FDG}$, or ${ }^{64} \mathrm{Cu}$-PTSM was administered at that time point. Inflammation was verified visually by inspection of the draining lymph node.

PET Studies. CFA-injected mice were anesthetized using isoflurane $/ \mathrm{O}_{2}(1.5 \%-2 \% \mathrm{v} / \mathrm{v})$ and injected with $1.85-3.7 \mathrm{MBq}$ $(50-100 \mu \mathrm{Ci})$ of ${ }^{18} \mathrm{~F}-\mathrm{PC}-10,{ }^{18} \mathrm{~F}-\mathrm{FDG}$, or ${ }^{64} \mathrm{Cu}-\mathrm{PTSM}$ in a volume of $100 \mu \mathrm{L}$ of PBS. For blocking experiments, 1.85-3.7 MBq (50$100 \mu \mathrm{Ci}$ ) of ${ }^{18} \mathrm{~F}-\mathrm{PC}-10$ were coinjected with $350 \mu \mathrm{g}$ of unlabeled PC-7. PET scans were obtained using an Inveon DPET scanner (Siemens Medical Solutions) at $0.5,1$, and $2 \mathrm{~h}$ after injection. Each group contained 3-5 mice. The images were reconstructed by a 3-dimensional ordered-subsets expectation maximum algorithm, and no correction was applied for attenuation or scatter. Images were analyzed using ASI Pro VM software. The percentage injected dose per gram $(\% \mathrm{ID} / \mathrm{g})$ for the various tissues was determined by drawing regions of interest surrounding the paws on the coronal images. The radioactivity contained in the region of interest divided by the dose administered to the animal gave the \%ID, and the volume of the region of interest was converted to mass assuming a density of 1 for the tissue.

Biodistribution. At $2 \mathrm{~h}$ after injection of ${ }^{18} \mathrm{~F}-\mathrm{PC}-10$, mice were anesthetized and their blood was drawn from the heart. The liver, muscle, kidneys, gastrointestinal tract, bone, salivary gland, and control and inflamed paws were removed. The organs were weighed and assayed for radioactivity using a $\gamma$-counter (1480 Wizard 3; Perkin-Elmer). Each group contained 4-5 mice.

\section{Statistical Analysis}

Results were expressed as mean \pm SD. Two-tailed paired and unpaired Student $t$ tests were used to determine differences within groups and between groups, respectively. $P$ values of less than 0.05 were considered statistically significant.

\section{RESULTS}

\section{Synthesis of PC-10}

The nonpeptidic PKR1 antagonist PC-7 was synthesized according to a published procedure (29). PC-7 was coupled with 4-fluorobenzoic acid for $1 \mathrm{~h}$ at $100^{\circ} \mathrm{C}$ using the coupling reagents $N$-(3-dimethylaminopropyl)- $N$-ethylcarbodiimide hydrochloride and 1-hydroxybenzotriazole to give PC-10 as a white powder in a $40 \%$ yield (Fig. 1A). 


\section{Radiosynthesis of ${ }^{18} \mathrm{~F}-\mathrm{PC}-10$}

${ }^{18} \mathrm{~F}-\mathrm{SFB}$ conjugation to $\mathrm{PC}-7$ occurred on a free guanidine group in the presence of a base (Fig. 1B). The conjugation was done with moderate heating for $10 \mathrm{~min}$. Analytic HPLC was performed to follow the conversion to the desired ${ }^{18} \mathrm{~F}-\mathrm{PC}-10$ and the consumption of ${ }^{18} \mathrm{~F}-\mathrm{SFB}$.

When only $100 \mu \mathrm{g}$ of PC-7 were used, there was still unreacted ${ }^{18} \mathrm{~F}$-SFB (Rt, $10.91 \mathrm{~min}$ ) remaining, as detected by analytic HPLC (Fig. 2). There is also a formation of ${ }_{4-}^{18} \mathrm{~F}$-fluorobenzoic acid (Rt, $4.09 \mathrm{~min}$ ) due to the basic conditions of the coupling reaction. The formation of ${ }^{18} \mathrm{~F}-\mathrm{PC}-10$ can be clearly seen by elution of the radioactive peak at a Rt of $25.81 \mathrm{~min}$ (Fig. 2). There are several other unidentifiable radioactive peaks formed during the coupling reaction.

${ }^{18} \mathrm{~F}-\mathrm{PC}-10$ was purified on a reversed-phase HPLC system and was achieved with radiochemical and chemical purities both greater than $99 \%$ and a specific activity of $70.3 \pm 7.4 \mathrm{TBq} / \mathrm{mmol}(1,900 \pm 200 \mathrm{Ci} / \mathrm{mmol})$ at the end of synthesis. The overall decay-corrected yield of ${ }^{18} \mathrm{~F}-\mathrm{PC}$ 10 was $16 \% \pm 3 \%(n=4)$, based on ${ }^{18} \mathrm{~F}$-fluoride radioactivity at the start of synthesis. The average total synthesis time, including HPLC purification and formulation, was about $160 \mathrm{~min}$.

\section{Competitive Binding Assay with ${ }^{125}$ I-MIT-1}

The affinity of PC-10 to $\mathrm{CHO}$ cells transfected with either human PKR1 or human PKR2 was evaluated in a competitive binding assay with the commercially available Bv8 homolog MIT-1, labeled with ${ }^{125}$ I ( $\left.{ }^{125} \mathrm{I}-\mathrm{MIT}-1\right)$. The $\mathrm{IC}_{50}$ of PC-10 binding to CHO-PKR1 cells was much lower than that achieved for PC-10 binding to CHO-PKR2 cells $(109.7 \pm 4.91$ vs. $1,200 \pm 69.47 \mathrm{nM}$, respectively). The binding affinity of PC-10 to PKR1 is 3-fold lower than the functional $\mathrm{IC}_{50}$ of PC-7 $(33 \mathrm{nM})$ required to induce calcium mobilization in human PKR1-expressing cells, as previously reported in the literature (29).

\section{Uptake, Internalization, and Efflux Studies}

The cell uptake, internalization, and efflux of ${ }^{18} \mathrm{~F}-\mathrm{PC}-10$ were evaluated in $\mathrm{CHO}-\mathrm{PKR} 1$ cells. ${ }^{18} \mathrm{~F}-\mathrm{PC}-10$ uptake increased between $15 \mathrm{~min}$ and $0.5 \mathrm{~h}$ (Fig. 3A), reached a plateau at $0.5 \mathrm{~h}$, and remained at a similar level for up to $1 \mathrm{~h}$. There was a slight decrease in the uptake between 1 and $2 \mathrm{~h}$ (Fig. 3A). To evaluate the internalization of the tracer, cells were treated with acid buffer $(\mathrm{pH} 2.8)$ before the final wash. Approximately half of the observed uptake was due to internalization of ${ }^{18} \mathrm{~F}-\mathrm{PC}-10$ into the cells. The internalization also reached a plateau at $0.5 \mathrm{~h}$, remaining stable up to $2 \mathrm{~h}$ after incubation. Retention studies showed a rapid release of ${ }^{18} \mathrm{~F}-\mathrm{PC}-10$ by $\mathrm{CHO}-\mathrm{PKR} 1$, and within 15 min after the replacement of the medium, half of the activity was unbound and reached a plateau after $1 \mathrm{~h}$.

\section{PET and Biodistribution}

The targeting efficiency of ${ }^{18} \mathrm{~F}-\mathrm{PC}-10$ in a CFA-induced inflammatory pain model in mice was evaluated by static small-animal PET scans. ${ }^{18}$ F-PC-10 had clearly higher accumulation in the inflamed paw than in the control paw (Fig. 3B). ${ }^{18} \mathrm{~F}-\mathrm{PC}-10 \mathrm{had}$ an uptake of $0.95 \pm 0.20 \% \mathrm{ID} / \mathrm{g}$ in the inflamed paw at $0.5 \mathrm{~h}$ after injection. This uptake was slightly increased at $1 \mathrm{~h}(1.21 \pm 0.32 \% \mathrm{ID} / \mathrm{g}$, Fig. 4A). At $2 \mathrm{~h}$ after injection, the uptake decreased to $0.78 \pm 0.04 \% \mathrm{ID} / \mathrm{g}$ in the inflamed paw and from $0.25 \pm 0.06 \% \mathrm{ID} / \mathrm{g}$ to $0.13 \pm$ $0.01 \% \mathrm{ID} / \mathrm{g}$ in the control paw (Fig. 4A). At all time points,

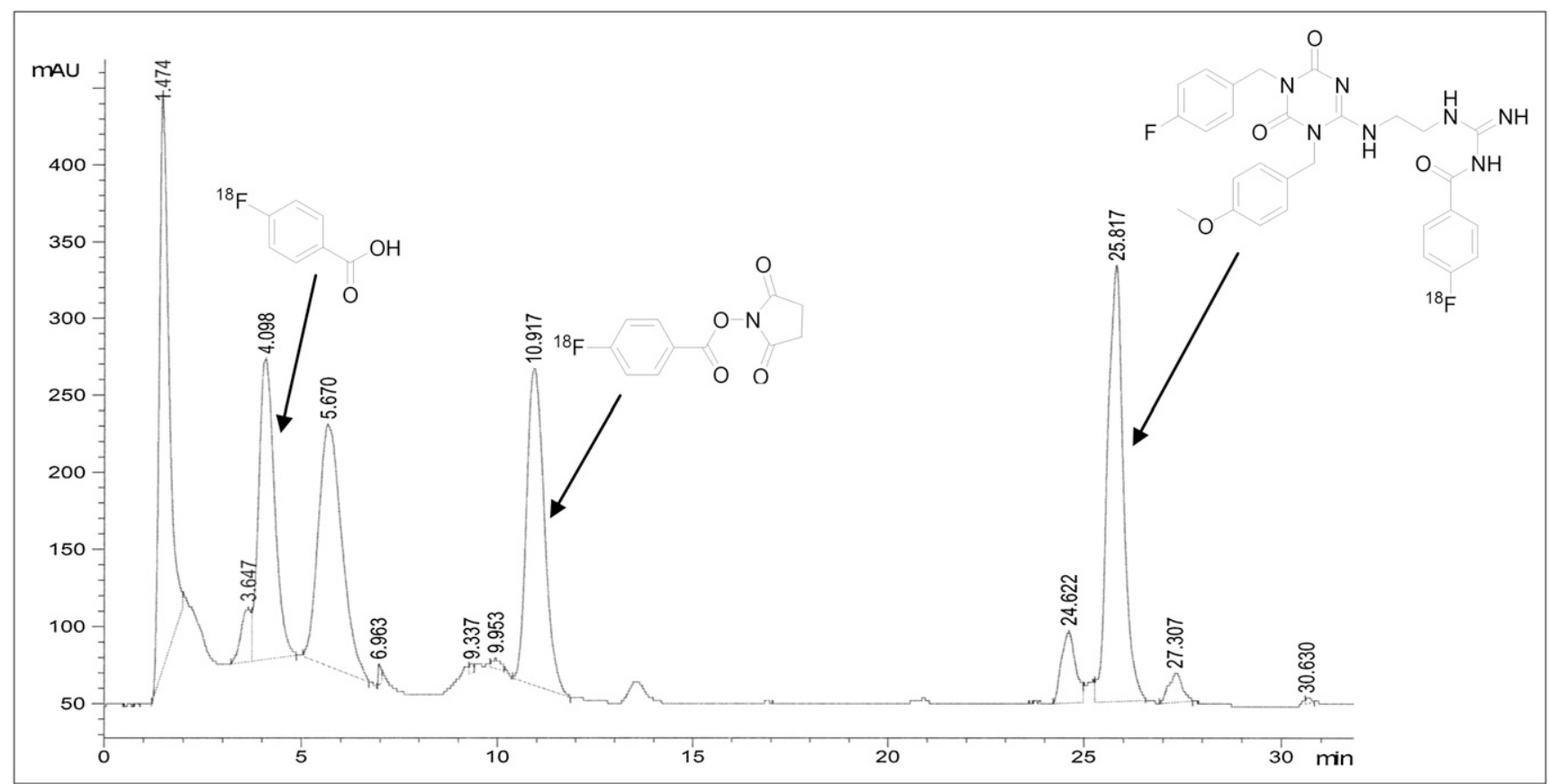

FIGURE 2. Radioactive analytic HPLC of crude sample of conjugation reaction of PC-7 (100 $\mu \mathrm{g})$ with ${ }^{18} \mathrm{~F}-\mathrm{SFB}$ to give ${ }^{18} \mathrm{~F}-\mathrm{PC}-10 . \mathrm{mAU}=$ milliabsorbance unit. 


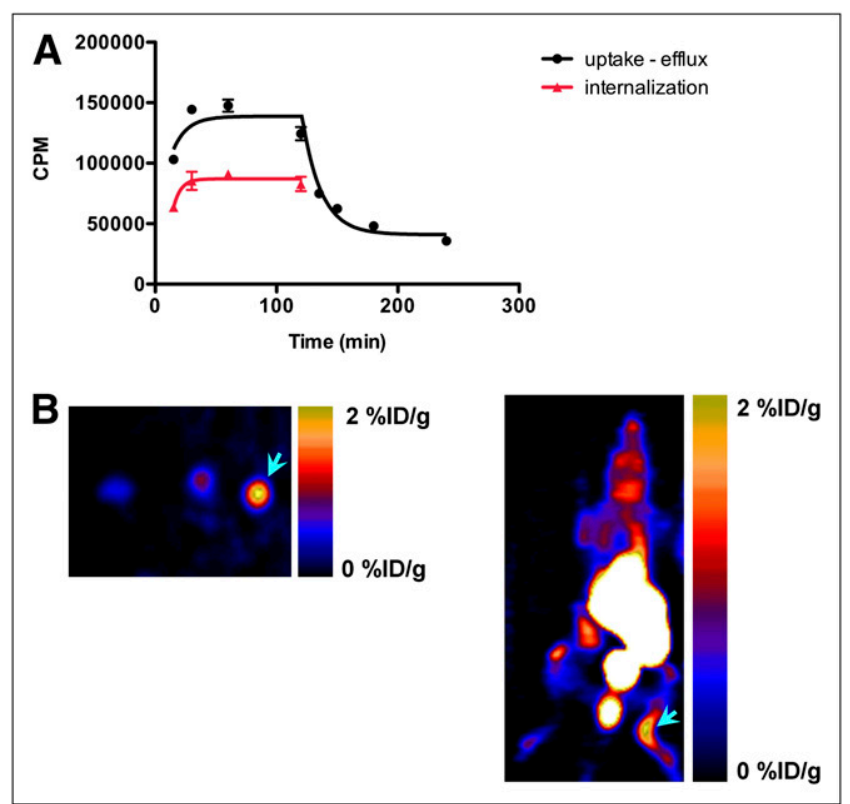

FIGURE 3. (A) Cell uptake, internalization, and efflux assays of ${ }^{18} \mathrm{~F}-\mathrm{PC}-10$ in $\mathrm{CHO}-\mathrm{PKR} 1$ cells. (B) Representative coronal (right) and axial (left) PET images of a C57BL/6 mouse injected with CFA into right paw at $1 \mathrm{~h}$ after injection with $3.7 \mathrm{MBq}(100 \mu \mathrm{Ci})$ of ${ }^{18} \mathrm{~F}-\mathrm{PC}-$ 10. Arrows indicate inflamed paw. CPM $=$ counts per min.

${ }^{18} \mathrm{~F}-\mathrm{PC}-10$ uptake in the inflamed paw was significantly higher than in the control paw $(P<0.01$, Fig. 4 A).

To determine the PKR1 specificity of ${ }^{18} \mathrm{~F}-\mathrm{PC}-10$ in vivo, CFA-treated mice were coinjected with ${ }^{18} \mathrm{~F}-\mathrm{PC}-10$ and an excess amount of the potent PKR1 antagonist PC-7. The uptake in the inflamed paw decreased significantly by approximately
$70 \%$ at $1 \mathrm{~h}$ after injection $(0.35 \pm 0.01 \% \mathrm{ID} / \mathrm{g})$, confirming specific binding of ${ }^{18} \mathrm{~F}-\mathrm{PC}-10$ to PKR1 (Fig. 4A).

${ }^{18} \mathrm{~F}-\mathrm{PC}-10$ also accumulated in PKR1-expressing organs (Figs. 3B and 4B), such as the salivary gland $(3.05 \pm 1.10$ $\% \mathrm{ID} / \mathrm{g}$ at $2 \mathrm{~h}$ after injection) and gastrointestinal tract (54.3 \pm $2.5 \% \mathrm{ID} / \mathrm{g}$ at $2 \mathrm{~h}$ after injection). ${ }^{18} \mathrm{~F}-\mathrm{PC}-10 \mathrm{had}$ fast clearance from the blood $(0.22 \pm 0.05 \% \mathrm{ID} / \mathrm{g}$ at $2 \mathrm{~h}$ after injection) and moderate uptake in the liver and kidneys $(3.80 \pm 1.14$ and $5.26 \pm 1.06 \% \mathrm{ID} / \mathrm{g}$, respectively, at $2 \mathrm{~h}$ after injection, Fig. 4B). ${ }^{18} \mathrm{~F}-\mathrm{PC}-10$ uptake in the bone was low $(0.69 \pm 0.12$ $\% \mathrm{ID} / \mathrm{g}$ at $2 \mathrm{~h}$ after injection, Fig. $4 \mathrm{~B}$ ), suggesting that there is no significant defluorination in vivo.

To compare the efficiency of ${ }^{18} \mathrm{~F}-\mathrm{PC}-10$ as a biomarker for inflammation, CFA-treated mice were injected with ${ }^{18} \mathrm{~F}$ FDG-which measures glucose metabolism rate and is known to accumulate in inflammatory foci $(32,33)$ - and scanned at $0.5,1$, and $2 \mathrm{~h}$ after injection (Fig. 5A). At all time points, ${ }^{18} \mathrm{~F}-$ FDG uptake was higher than ${ }^{18} \mathrm{~F}-\mathrm{PC}-10$ uptake in the inflamed paw. For example, at $1 \mathrm{~h},{ }^{18} \mathrm{~F}-\mathrm{FDG}$ uptake in the inflamed paw was $4.98 \pm 0.28 \% \mathrm{ID} / \mathrm{g}$ (Fig. 5A), which is almost 5 times higher than the uptake achieved with ${ }^{18} \mathrm{~F}-\mathrm{PC}$ 10. This difference was further increased at $2 \mathrm{~h}$ after injection, because ${ }^{18} \mathrm{~F}-\mathrm{PC}-10$ started to undergo clearance. ${ }^{18} \mathrm{~F}$-FDG uptake in the inflamed paw, however, remained stable and high, because of its retention mechanism within the cell $(5.21 \pm 0.29 \% \mathrm{ID} / \mathrm{g}$, Figs. 4A and 5A).

In addition, ${ }^{18} \mathrm{~F}-\mathrm{PC}-10$ uptake in the inflamed paw was compared with CFA-treated mice injected with the perfusion imaging agent ${ }^{64} \mathrm{Cu}$-PTSM. ${ }^{64} \mathrm{Cu}$-PTSM also had higher uptake in the inflamed paw than did ${ }^{18} \mathrm{~F}-\mathrm{PC}-10$ at all time points (Fig. 5B). ${ }^{64} \mathrm{Cu}-\mathrm{PTSM}$ uptake in the
FIGURE 4. (A) Uptake of ${ }^{18} \mathrm{~F}-\mathrm{PC}-10$ in inflamed, control, and inflamed-block paws of C57BL/6 mice, treated with CFA at $24 \mathrm{~h}$ before imaging and at $0.5,1$, and $2 \mathrm{~h}$ after injection. Results are calculated from PET scans and are shown as averages of $4-5$ mice \pm SD. (B) Biodistribution of C57BL/6 CFA-treated mice injected with ${ }^{18} \mathrm{~F}-\mathrm{PC}-10$ at $2 \mathrm{~h}$ after injection. Results shown are averages of $4-5$ mice $\pm S D$. CTRL $=$ control. ${ }^{*} P<0.01$ vs. control paw. ${ }^{\#} P<0.05$ vs. inflamed-block paw.

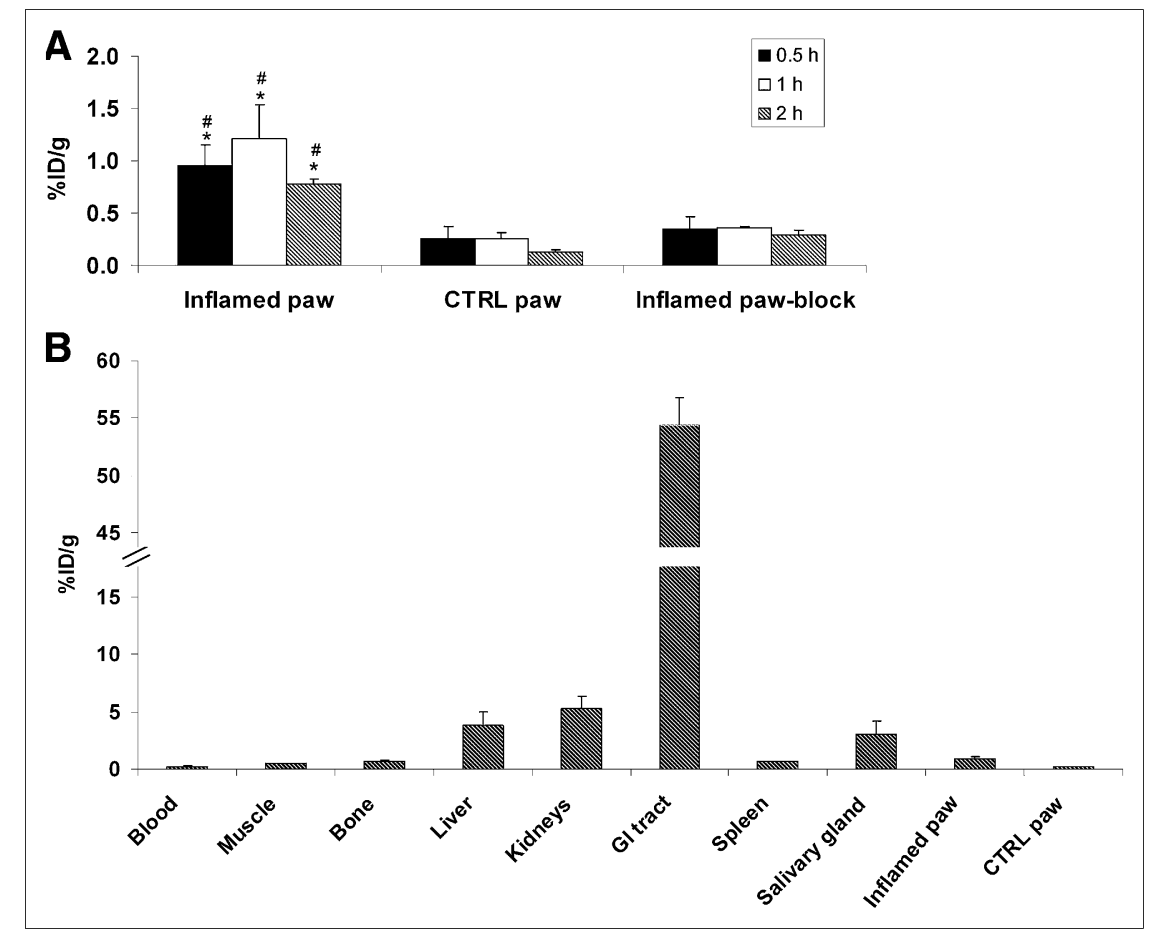



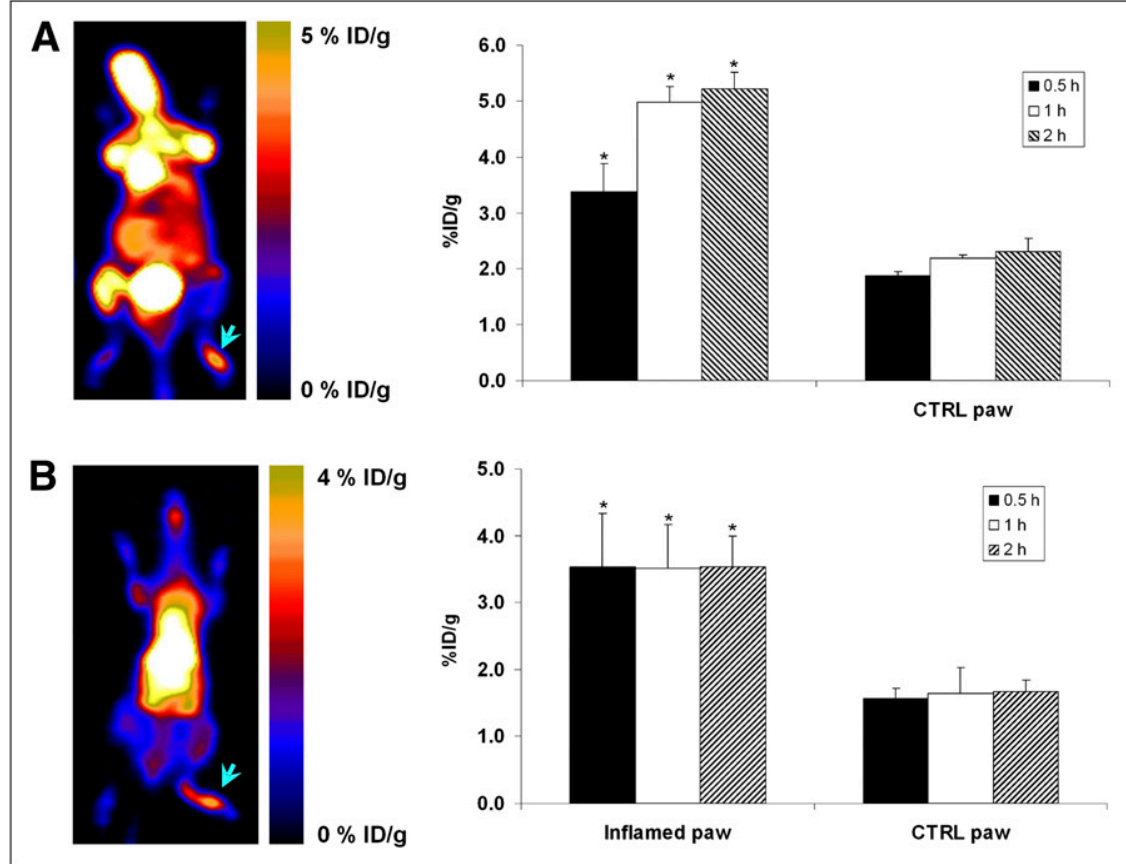

FIGURE 5. (A; left) Representative coronal PET image of C57BL/6 mouse injected with CFA into right paw at $1 \mathrm{~h}$ after injection with $3.7 \mathrm{MBq}(100 \mu \mathrm{Ci})$ of ${ }^{18} \mathrm{~F}-\mathrm{FDG}$. (Right) Uptake of ${ }^{18} \mathrm{~F}-\mathrm{FDG}$ in inflamed and control paws of C57BL/ 6 mice, treated with CFA at $24 \mathrm{~h}$ before imaging and at $0.5,1$, and $2 \mathrm{~h}$ after injection. Results are calculated from PET scans and are shown as averages of 3-4 mice \pm SD. (B; left) Representative coronal PET image of C57BL/6 mouse injected with CFA into right paw at $1 \mathrm{~h}$ after injection with $3.7 \mathrm{MBq}(100 \mu \mathrm{Ci})$ of ${ }^{64} \mathrm{Cu}$ PTSM. (Right) Uptake of ${ }^{64} \mathrm{Cu}-\mathrm{PTSM}$ in inflamed and control paws of C57BL/6 mice, treated with CFA at $24 \mathrm{~h}$ before imaging and at $0.5,1$, and $2 \mathrm{~h}$ after injection. Results are calculated from PET scans and are shown as averages of 3-4 mice \pm SD. $\mathrm{CTRL}=$ control. ${ }^{\star} P<0.01$ vs. control paw. inflamed and control paws was stable at all time points $(\sim 3.50 \% \mathrm{ID} / \mathrm{g}$ in the inflamed paw and $1.60 \% \mathrm{ID} / \mathrm{g}$ in the control paw, Fig. 5B).

Uptake in the control paw was much higher for both ${ }^{18} \mathrm{~F}-$ FDG and ${ }^{64} \mathrm{Cu}-\mathrm{PTSM}$ than for ${ }^{18} \mathrm{~F}-\mathrm{PC}-10 .{ }^{18} \mathrm{~F}-\mathrm{FDG}$ and ${ }^{64} \mathrm{Cu}$-PTSM uptake in the inflamed paw was only 2-fold higher than in the control paw (Fig. 5). In contrast, ${ }^{18} \mathrm{~F}-$ PC-10 uptake was 4-5 times higher in the inflamed paw than in the control paw (Fig. 4). The ratios between the inflamed and control paws at all time points show that the inflamed paw-to-control paw ratio is higher for ${ }^{18} \mathrm{~F}-\mathrm{PC}-10$ than for either ${ }^{18} \mathrm{~F}-\mathrm{FDG}$ or ${ }^{64} \mathrm{Cu}$-PTSM (Fig. 6).

\section{DISCUSSION}

Prokineticin receptors are G-protein-coupled receptors belonging to the neuropeptide $\mathrm{Y}$ receptor class, and their importance is emphasized by the fact that one of their ligands, MIT, is present in snake venom (5). The prokineticin 2-PKR1 axis was shown to be expressed in inflamed tissue and was suggested as a link between cells infiltrating the inflamed tissue and the development of inflammatory pain (23). Giannini et al. have demonstrated that the development and duration of CFA-induced hyperalgesia correlates with the messenger RNA expression level of prokineticin 2 in the inflamed paw, and they have shown that $24 \mathrm{~h}$ after CFA induction, there is elevation in messenger RNA expression of PKR1 (23). One possible explanation for higher PKR1 expression in the inflamed tissue is that prokineticin 2, which was also shown to have chemotactic capability, induces accumulation of cells that express its receptor.

To quantify PKR1 levels in inflammation induced by CFA injection, we modified the known nonpeptidic PKR1 antagonist PC-7 (29). PC-7 contains a free guanidine group

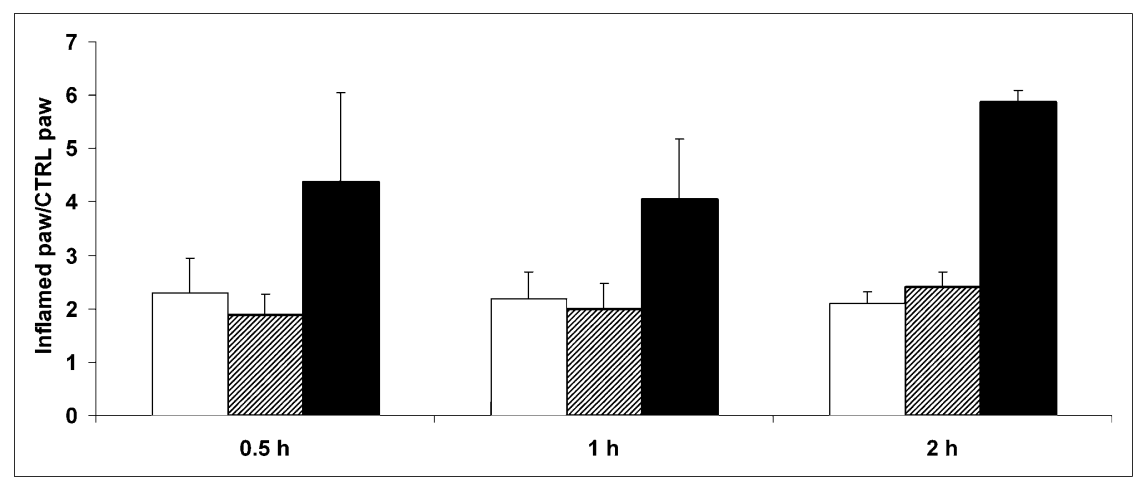

FIGURE 6. Inflamed paw-to-control paw ratios of either ${ }^{64} \mathrm{Cu}$-PTSM (white bars), ${ }^{18} \mathrm{~F}-\mathrm{FDG}$ (hatched bars), or ${ }^{18} \mathrm{~F}-\mathrm{PC}-10$ (black bars) at $0.5,1$, and $2 \mathrm{~h}$ after injection. Results shown are averages of 3-5 mice \pm $\mathrm{SD}$. CTRL = control. 
and was conjugated with $p$-fluorobenzoic acid to give PC10 (Fig. 1A). The affinity of PC-10 to PKR1 and PKR2 was tested and demonstrates that PC-10 is more selective and potent to PKR1 than to PKR2.

PC-7 was also used as a precursor for the labeling with ${ }^{18} \mathrm{~F}$ (Fig. 1B). PC-10 was labeled with ${ }^{18} \mathrm{~F}$ via conjugation of $\mathrm{PC}-7$ with ${ }^{18} \mathrm{~F}$-SFB. ${ }^{18} \mathrm{~F}-\mathrm{SFB}$ is a prosthetic group, which is usually used in peptide labeling for coupling to $\varepsilon$ - or $\alpha$-amino groups $(31,34,35)$. PC-7 was conjugated with ${ }^{18} \mathrm{~F}-\mathrm{SFB}$ in dimethylformamide in the presence of a base and for a short reaction time. One of the byproducts of the coupling reaction was ${ }^{18} \mathrm{~F}$ fluorobenzoic acid (Fig. 2). Because the reaction was conducted in dimethylformamide and base (diisopropylethyl amine), the formation of both ${ }^{18} \mathrm{~F}-\mathrm{PC}-10$ and ${ }^{18} \mathrm{~F}$-fluorobenzoic acid was rapid. Increasing the amount of PC-7 used for the radiosynthesis (from 100 to $200 \mu \mathrm{g}$ ) resulted in a higher radiochemical yield of ${ }^{18} \mathrm{~F}-\mathrm{PC}-10$ and complete elimination of ${ }^{18} \mathrm{~F}-\mathrm{SFB}$. Increasing the amount of PC-7 even more did not change significantly the reaction kinetic and yield. Unreactive PC-7 was detected by ultraviolet absorbance (data not shown). Attempts to use only $100 \mu \mathrm{g}$ of PC-7 resulted in unreactive ${ }^{18}$ F-SFB (Fig. 2). When additional base was added to improve the conversion to ${ }^{18} \mathrm{~F}-\mathrm{PC}-10$, decomposition of ${ }^{18} \mathrm{~F}-\mathrm{SFB}$ to ${ }^{18} \mathrm{~F}$-fluorobenzoic acid was detected, along with an overall decrease in the radiochemical yield of desired product.

Inflammation-related pain was induced in C57BL/6 mice by subcutaneous injection of CFA into the right paw, and 24 $\mathrm{h}$ later, the mice were injected intravenously with ${ }^{18} \mathrm{~F}-\mathrm{PC}$ 10. ${ }^{18} \mathrm{~F}-\mathrm{PC}-10$ was clearly visualized in the inflamed paw (Figs. 3B), and the uptake in the inflamed paw was 4- to 5fold higher at all time points $(0.5,1$, and $2 \mathrm{~h})$ than the uptake in the control paw (Fig. 4A). ${ }^{18} \mathrm{~F}-\mathrm{PC}-10$ uptake in the inflamed paw was decreased at $2 \mathrm{~h}$ after injection, suggesting that the optimal imaging time with ${ }^{18} \mathrm{~F}-\mathrm{PC}-10$ should not exceed $2 \mathrm{~h}$ after injection. This result is in accordance with the cell studies, with optimal uptake of ${ }^{18} \mathrm{~F}$-PC-10 at $1 \mathrm{~h}$ after incubation and some reduction in the activity on the cells at $2 \mathrm{~h}$. Blocking studies by coinjection of ${ }^{18} \mathrm{~F}-\mathrm{PC}-10$ and the more potent PKR1 antagonist PC-7 (which has a chemical structure similar to that of PC-10) showed a significant decrease in the inflamed paw uptake, suggesting a specific binding to PKR1 (Fig. 4A).

${ }^{18}$ F-PC-10 also displayed uptake in PKR1-expressing organs, such as the salivary gland and gastrointestinal tract. Low uptake in the kidneys and liver (Fig. 4B) and increased uptake in the gastrointestinal tract suggest that the main clearance route of ${ }^{18} \mathrm{~F}-\mathrm{PC}-10$ is via the small intestine and colon, which means that the radioactivity in the gastrointestinal tract is not solely due to specific binding to PKR1. Clearance via the gastrointestinal tract could possibly be because of the lipophilicity of ${ }^{18}$ F-PC-10, and modification of the small molecule to be more hydrophilic might change the pharmacokinetics and enable the visualization of specific binding of ${ }^{18} \mathrm{~F}-\mathrm{PC}-10$ to PKR1 in the lower abdomen, including the intestine. The high uptake in the intestine is most unfortunate, because several conditions could induce inflammatory pain in this organ (36).

Another issue that we addressed here was the possibility that the higher accumulation in the inflamed paw was due to the inflammatory process, which may cause regional increases in blood flow, vascular permeability, and extracellular volume that result in nonspecific uptake of biomarkers. For these reasons, we compared ${ }^{18} \mathrm{~F}-\mathrm{PC}-10$ uptake with ${ }^{18} \mathrm{~F}-\mathrm{FDG}$ and ${ }^{64} \mathrm{Cu}-\mathrm{PTSM}$ uptake in the inflamed paw. ${ }^{18} \mathrm{~F}-\mathrm{FDG}$ measures the glucose metabolic rate and is mainly used as a cancer imaging agent but also accumulates in inflammatory lesions $(32,33) .{ }^{64} \mathrm{Cu}$-PTSM is known as a perfusion imaging biomarker and should be able to determine blood flow to the region $(37,38)$.

${ }^{18} \mathrm{~F}-\mathrm{FDG}$ and ${ }^{64} \mathrm{Cu}$-PTSM had 2-fold higher uptake in the inflamed paw than in the control paw at all time points, implying that there is high blood flow in the CFA-treated animal model that we used. Neither of these tracers is specific. They can give information regarding perfusion and metabolism but cannot give any biochemical information regarding the inflammation. Although ${ }^{18} \mathrm{~F}-\mathrm{FDG}$ and ${ }^{64} \mathrm{Cu}-\mathrm{PTSM}$ had significantly higher uptake than ${ }^{18} \mathrm{~F}-\mathrm{PC}-10$ in the inflamed paw (Figs. 4A and 5), they also had significantly higher uptake than ${ }^{18} \mathrm{~F}$-PC-10 in the control paw (10-fold higher).

Therefore, a comparison of the ratio of inflamed paw to control paw (Fig. 6) shows that ${ }^{18} \mathrm{~F}$-PC-10 has an advantage over ${ }^{18} \mathrm{~F}-\mathrm{FDG}$ and ${ }^{64} \mathrm{Cu}-\mathrm{PTSM}$ in term of less background (less accumulation in the control paw), leading to higher PET image contrast between the inflamed and control paws. In addition, ${ }^{18} \mathrm{~F}-\mathrm{PC}-10$ binds specifically to PKR1 in vivo and gives information that might be helpful for therapeutic intervention for inflammation-related pain.

\section{CONCLUSION}

Overall, we successfully labeled the selective nonpeptidic PKR1 ligand ${ }^{18} \mathrm{~F}-\mathrm{PC}-10$. A CFA injection induced ${ }^{18} \mathrm{~F}-\mathrm{PC}-10$ specific uptake in the inflamed paw that expressed PKR1. ${ }^{18}$ F-PC-10 showed a higher inflamed paw-to-control paw ratio than ${ }^{18} \mathrm{~F}$-FDG and ${ }^{64} \mathrm{Cu}-\mathrm{PTSM}$, resulting in better PET contrast. PKR1 and PKR2 should be further investigated as potential targets for the imaging of pain. More hydrophilic imaging agents can be developed and may improve the image quality.

\section{ACKNOWLEDGMENTS}

We thank Weihua Li for skillful assistance with data acquisition and Dr. Roberta Lattanzi for the preliminary in vivo assay of cold PC-10. This research was supported in part by the Intramural Research Program (IRP) of the National Institute of Biomedical Imaging and Bioengineering (NIBIB), National Institute of Allergy and Infectious Diseases (NIAID), National Institutes of Health (NIH), International Cooperative Program of National Science Foundation of China (NSFC) (81028009), and Italian Ministry of University and Scientific Research (PRIN 2007). 


\section{REFERENCES}

1. Lin DC, Bullock CM, Ehlert FJ, Chen JL, Tian H, Zhou QY. Identification and molecular characterization of two closely related $G$ protein-coupled receptors activated by prokineticins/endocrine gland vascular endothelial growth factor. $J$ Biol Chem. 2002;277:19276-19280.

2. Masuda Y, Takatsu Y, Terao Y, et al. Isolation and identification of EG-VEGF/ prokineticins as cognate ligands for two orphan G-protein-coupled receptors. Biochem Biophys Res Commun. 2002;293:396-402.

3. Soga T, Matsumoto S, Oda T, et al. Molecular cloning and characterization of prokineticin receptors. Biochim Biophys Acta. 2002;1579:173-179.

4. Zhou QY. The prokineticins: a novel pair of regulatory peptides. Mol Interv. 2006;6:330-338.

5. Negri L, Lattanzi R, Giannini E, Melchiorri P. Bv8/prokineticin proteins and their receptors. Life Sci. 2007;81:1103-1116.

6. Cheng MY, Bullock CM, Li C, et al. Prokineticin 2 transmits the behavioural circadian rhythm of the suprachiasmatic nucleus. Nature. 2002;417:405-410.

7. Mollay C, Wechselberger C, Mignogna G, et al. Bv8, a small protein from frog skin and its homologue from snake venom induce hyperalgesia in rats. Eur $J$ Pharmacol. 1999;374:189-196.

8. Zhou QY, Cheng MY. Prokineticin 2 and circadian clock output. FEBS J. 2005;272:5703-5709.

9. Li M, Bullock CM, Knauer DJ, Ehlert FJ, Zhou QY. Identification of two prokineticin cDNAs: recombinant proteins potently contract gastrointestinal smooth muscle. Mol Pharmacol. 2001;59:692-698.

10. Bullock CM, Li JD, Zhou QY. Structural determinants required for the bioactivities of prokineticins and identification of prokineticin receptor antagonists. $\mathrm{Mol}$ Pharmacol. 2004;65:582-588.

11. LeCouter J, Kowalski J, Foster J, et al. Identification of an angiogenic mitogen selective for endocrine gland endothelium. Nature. 2001;412:877-884.

12. LeCouter J, Lin R, Tejada M, et al. The endocrine-gland-derived VEGF homologue Bv8 promotes angiogenesis in the testis: localization of Bv8 receptors to endothelial cells. Proc Natl Acad Sci USA. 2003;100:2685-2690.

13. Melchiorri D, Bruno V, Besong G, et al. The mammalian homologue of the novel peptide Bv8 is expressed in the central nervous system and supports neuronal survival by activating the MAP kinase/PI-3-kinase pathways. Eur J Neurosci. 2001;13:1694-1702.

14. Matsumoto S, Yamazaki C, Masumoto KH, et al. Abnormal development of the olfactory bulb and reproductive system in mice lacking prokineticin receptor PKR2. Proc Natl Acad Sci USA. 2006;103:4140-4145.

15. Masumoto KH, Nagano M, Takashima N, et al. Distinct localization of prokineticin 2 and prokineticin receptor 2 mRNAs in the rat suprachiasmatic nucleus. Eur J Neurosci. 2006;23:2959-2970.

16. Schweitz H, Pacaud P, Diochot S, Moinier D, Lazdunski M. MIT(1), a black mamba toxin with a new and highly potent activity on intestinal contraction. FEBS Lett. 1999;461:183-188.

17. LeCouter J, Zlot C, Tejada M, Peale F, Ferrara N. Bv8 and endocrine glandderived vascular endothelial growth factor stimulate hematopoiesis and hematopoietic cell mobilization. Proc Natl Acad Sci USA. 2004;101:16813-16818.

18. Martucci C, Franchi S, Giannini E, et al. Bv8, the amphibian homologue of the mammalian prokineticins, induces a proinflammatory phenotype of mouse macrophages. Br J Pharmacol. 2006;147:225-234.

19. Shojaei F, Wu X, Zhong C, et al. Bv8 regulates myeloid-cell-dependent tumour angiogenesis. Nature. 2007;450:825-831.
20. Negri L, Lattanzi R, Giannini E, et al. Nociceptive sensitization by the secretory protein Bv8. Br J Pharmacol. 2002;137:1147-1154.

21. Negri L, Lattanzi R, Giannini E, et al. Impaired nociception and inflammatory pain sensation in mice lacking the prokineticin receptor PKR1: focus on interaction between PKR1 and the capsaicin receptor TRPV1 in pain behavior. $J$ Neurosci. 2006;26:6716-6727.

22. Negri L, Lattanzi R, Giannini E, Melchiorri P. Modulators of pain: Bv8 and prokineticins. Curr Neuropharmacol. 2006;4:207-215.

23. Giannini E, Lattanzi R, Nicotra A, et al. The chemokine Bv8/prokineticin 2 is up-regulated in inflammatory granulocytes and modulates inflammatory pain. Proc Natl Acad Sci USA. 2009;106:14646-14651.

24. Balboni G, Lazzari I, Trapella C, et al. Triazine compounds as antagonists at Bv8-prokineticin receptors. J Med Chem. 2008;51:7635-7639.

25. Coats SJ, Dyatkin AB, He W, Lisko J, Ralbovsky JL, Schultz MJ, inventors; Janssen Pharmaceutica, N.V., assignee. Prokineticin 1 receptor antagonists. Patent WO2006104715. October 5, 2006.

26. Coats SJ, Dyatkin AB, He W, Lisko J, Ralbovsky JL, Schultz MJ, inventors; Janssen Pharmaceutica, N.V., assignee. Pyrimidindione derivatives as prokineticin 2 receptor antagonists. Patent WO2006104713. October 5, 2006.

27. Coats SJ, Dyatkin AB, He W, Lisko J, Miskowski TA, Ralbovsky JL, Schultz MJ, inventors; Janssen Pharmaceutica, N.V., assignee. Prokineticin 2 receptor antagonists. Patent WO2007079214. July 12, 2007.

28. Thompson WJ, Melamed JY, inventors; Merck \& Co., assignee. Preparation of morpholinecarboxamides as prokineticin 2 receptor antagonists. Patent WO2007067511. June 14, 2007.

29. Ralbovsky JL, Lisko JG, Palmer JM, et al. Triazinediones as prokineticin 1 receptor antagonists: part 1-SAR, synthesis and biological evaluation. Bioorg Med Chem Lett. 2009;19:2661-2663.

30. Blower PJ, Lewis JS, Zweit J. Copper radionuclides and radiopharmaceuticals in nuclear medicine. Nucl Med Biol. 1996;23:957-980.

31. Jacobson O, Weiss ID, Kiesewetter DO, Farber JM, Chen X. PET of tumor CXCR4 expression with 4- ${ }^{18}$ F-T140. J Nucl Med. 2010;51:1796-1804.

32. Liu RS, Chou TK, Chang $\mathrm{CH}$, et al. Biodistribution, pharmacokinetics and PET imaging of $\left[{ }^{18} \mathrm{~F}\right] \mathrm{FMISO},\left[{ }^{18} \mathrm{~F}\right] \mathrm{FDG}$ and $\left[{ }^{18} \mathrm{~F}\right] \mathrm{FAc}$ in a sarcoma- and inflammation-bearing mouse model. Nucl Med Biol. 2009;36:305-312.

33. Hellwig D, Menges M, Schneider G, et al. Radioiodinated phenylalanine derivatives to image pancreatic cancer: a comparative study with [ $\left.{ }^{18} \mathrm{~F}\right]$ fluoro-2-deoxy-D-glucose in human pancreatic carcinoma xenografts and in inflammation models. Nucl Med Biol. 2005;32:137-145.

34. Chen X, Park R, Shahinian AH, et al. ${ }^{18}$ F-labeled RGD peptide: initial evaluation for imaging brain tumor angiogenesis. Nucl Med Biol. 2004;31:179-189.

35. Liu S, Liu Z, Chen K, et al. ${ }^{18}$ F-labeled galacto and PEGylated RGD dimers for PET imaging of alphavbeta3 integrin expression. Mol Imaging Biol. 2010;12:530538.

36. Lakhan SE, Kirchgessner A. Neuroinflammation in inflammatory bowel disease. J Neuroinflammation. 2010;7:37.

37. Basken NE, Green MA. Cu(II) bis(thiosemicarbazone) radiopharmaceutical binding to serum albumin: further definition of species dependence and associated substituent effects. Nucl Med Biol. 2009;36:495-504.

38. Adonai N, Nguyen KN, Walsh J, et al. Ex vivo cell labeling with ${ }^{64} \mathrm{Cu}$-pyruvaldehyde-bis(N4-methylthiosemicarbazone) for imaging cell trafficking in mice with positron-emission tomography. Proc Natl Acad Sci USA. 2002;99:3030-3035. 